\author{
ROBERT STEFANICKI \\ ORCID: 0000-0002-6087-4231 \\ Uniwersytet Wrocławski \\ Instytut Prawa Cywilnego \\ Zakład Prawa Gospodarczego i Handlowego
}

\title{
UN JUSTE ÉQUILIBRE. PRAWO NOŚNIKIEM WARTOŚCI. PRZYCZYNEK DO DYSKUSJI
}

\begin{abstract}
Abstrakt: Prawo powinno uosabiać uznawane przez daną społeczność wartości. Materialny wymóg praworządności odnosi się do zawartości pryncypiów, walorów konstruowanych na podstawie kryteriów aksjologicznych i prakseologicznych przedmiotowych norm. W responsywnym podejściu chodzi o racjonalne i wybiórcze sięganie do sygnałów płynących z otoczenia prawa, jego dyskursywnej otwartości połączonej z adekwatną edukacją adeptów jurydycznych profesji w zakresie tytułowej problematyki. Ewolucyjnie dokonujący się rozwój refleksyjnego podejścia do prawa, z jego otwartością na wymiar etyczny, może utorować drogę do postrzegania godności jednostki w kategorii samoistnego wzorca i podstawy skargi konstytucyjnej.
\end{abstract}

Słowa kluczowe: porządek prawny, kryteria aksjologiczne i prakseologiczne, dyskursywna otwartość, etyczny wymiar, model responsywny

Punktem wyjścia przedmiotowych rozważań należałoby uczynić usytuowanie prawa $\mathrm{w}$ kontekście wielu pozostających zresztą z sobą w związku instrumentów służących ochronie ładu społecznego. Porządek prawny nie jest jedynym regulatorem relacji społecznych. Należy go postrzegać w kategorii ważkiego mechanizmu służącego budowaniu i zabezpieczaniu w praktyce mechanizmów ochronnych społecznego porządku, norm celowościowych mających zagwarantować istnienie zbiorowości ludzkiej ${ }^{1}$. Zadanie stanowienia i stosowania prawa leży u jego podstaw. Żaden system prawa pozytywnego nie jest w stanie uzasadnić swej ważności per se, ponieważ nie jest bytem samoistnym, lecz porządkiem kształtowanym

${ }^{1}$ L. Duguit, Kierunki rozwoju prawa cywilnego od początku XIX wieku, przeł. S. Sieczkowski, Warszawa-Kraków 1938, s. 28. 
w celu ochrony ważnych dla danej społeczności wartości ${ }^{2}$. Nie każdy porządek wynikający z przestrzegania stanowionych reguł jest dobry, lecz tylko ten, w którym jego treść jest dobra. Inaczej mówiąc, nie wystarczy formalne trzymanie się litery prawa przez je wykonujących, ale samo prawo powinno uosabiać uznawane przez daną społeczność wartości ${ }^{3}$. Materialny wymóg praworządności odnosi się do zawartości prawa, wartości konstruowanych na podstawie kryteriów aksjologicznych i prakseologicznych praw.

Zasadniczy we współczesnej teorii i filozofii prawa spór skupia się wokół wykładni i metodologii odczytywania jego istoty, a więc i poszukiwania odpowiedzi na pytanie, czy w kwestii realizacji celów normowania zakładany jest wymóg jego autonomiczności i separacji od innych, zewnętrznych jego komponentów, czy dokonywać mamy jego interpretacji otwartej na zmiany otoczenia prawa i inne czynniki zewnętrzne. Autonomiczny model pojmowania prawa, a zatem i budowania instytucji służących jego realizacji zakłada neutralność systemu normatywnego wobec innych „subświatów”, w tym zwłaszcza czynników politycznych. Zasadniczym celem separacji jest przede wszystkim zachowanie instytucjonalnej integralności i spójności, co między innymi ma służyć zabezpieczeniu pewności prawa $^{4}$, nieobojętnej zresztą dla jego adresatów. Trafnie podnosi się $e^{5}$, że w imię takich wartości jak formalne pojmowanie sprawiedliwości podejście to propaguje nieskuteczne i ekonomicznie nieefektywne metody badania prawa i może prowadzić do powstania porządku normatywnego przeregulowanego i statycznego ${ }^{6}$. W opozycji do modelu formalno-dogmatycznego pozostaje koncepcja refleksyjnego interpretowania prawa i budowania adekwatnych do potrzeb instytucji jego

${ }^{2}$ Więcej R. Kwiecień, Wartości i prawo a kreatywność porządku prawnego, „Forum Prawnicze” 2010, nr 1 (1), s. 35.

${ }^{3}$ B. Banaszak, Konstytucja Rzeczpospolitej Polskiej. Komentarz, Warszawa 2009, s. 33.

${ }^{4} \mathrm{Na}$ temat konsekwencji ,uporczywego trwania przy dotychczasowych schematach narracyjnych i interpretacyjnych z punktu widzenia autonomizacji prawa i dyskursu konstytucyjnego" A. Sulikowski, K. Otręba, O potrzebie studiów krytycznych nad prawem konstytucyjnym, „Państwo i Prawo" 2017, nr 3, s. 11. Więcej w kwestii uzasadnienia odchodzenia od formalnodogmatycznego przestrzegania prawa L. Morawski, Główne problemy współczesnej filozofii prawa. Prawo w toku przemian, Warszawa 2005, s. 36 n., oraz instrumentów zapewniających obywatelowi możliwość skutecznego żądania od organów władzy publicznej określonego zachowania, w razie potrzeby egzekwowalnego w drodze odpowiednich instytucji procesowych, W. Sokolewicz, [w:] Konstytucja Rzeczypospolitej Polskiej. Komentarz, t. 4, red. L. Garlicki, Warszawa 2005, s. 5.

5 J. Stelmach, Pozytywistyczne mity metody prawniczej, „Forum Prawnicze” 2012, nr 3, s. 12.

${ }^{6}$ Por. też W. Gromski, Law and economics jako teoria polityki prawa, [w:] Analiza ekonomiczna w zastosowaniach prawniczych, red. J. Stelmach, M. Soniewicka, Warszawa 2007, s. 48. 
stosowania. Określa się ją również jako model responsywny ${ }^{7}$. Zgodnie z tym podejściem do tworzenia, rozumienia i stosowania prawa powinno być ono racjonalnie otwierane na fakty i zmiany społeczne ${ }^{8}$, zwłaszcza dostrzeganą ich dynamikę. Metodologia racjonalnego otwierania prawa oznacza zasadniczy zwrot $\mathrm{w}$ stronę dowartościowywania celu tworzonego prawa i zgodnie z nim odkrywania jego treści. Mechanizm ten nie ma odniesienia o charakterze bezwzględnym, a więc koncepcji, która byłaby niekontrolowana przez pryzmat wartości niesionych zwłaszcza przez konstytucję. Dotyczy to przede wszystkim problemu rozsądnej otwartości na czynniki i wpływy polityczne. W responsywnym podejściu chodzi o racjonalne i wybiórcze sięganie do sygnałów płynących z otoczenia prawa9 ${ }^{9}$ Nie sposób tu pominąć, że w ewolucji, jak się dokonywała w prawie, model autonomiczny był reakcją na nadmierne upolitycznienie modelu represyjnego ${ }^{10}$. Lekcja wyciągana ze stosowania zamkniętego, niezależnego porządku może być przydatna w racjonalnym i wybiórczym otwieraniu prawa na czynniki społecznej zmiany.

\section{III}

Zgodnie z responsywnym podejściem interpretacja prawa powinna być aksjologicznie otwarta. Nie jest to zadanie łatwe do zastosowania, zważywszy, że rzeczywistość nie jest homogeniczna. Pluralizm aksjologiczny oznacza przyjęcie, co do zasady, że istnieje wiele wartości i dóbr zasługujących na ochronę prawną, których jednocześnie zaspokoić nie można. Pojawia się więc konieczność ich zestawiania i ważenia ${ }^{11}$, aby w danych okolicznościach nadać pierwszeństwo jednej $\mathrm{z}$ nich, nie naruszając $\mathrm{w}$ tym procesie istoty poświęconego dobra ${ }^{12}$. W wielu sy-

${ }^{7}$ Zob. w tym zakresie uwagi A. Batora, P. Kaczmarka, Kim ma być wychowanek akademii prawniczej?: o perspektywach budowania edukacji prawniczej wokót konstytucji, „Krytyka Prawa” 2018, nr 2, s. 21 n., oraz cytowane przez autorów piśmiennictwo; M. Żak, O możliwych zastosowaniach idei good governance w naukach prawnych i praktyce prawniczej, „Państwo i Prawo” 2019, nr 9, s. 62; J. Jacyszyn, Dobre praktyki spółek giełdowych, „Przegląd Ustawodawstwa Gospodarczego” 2016, nr 2, s. 2 n.

${ }^{8}$ M. Korycka-Zirk, Filozoficznoprawny wymiar kontroli konstytucyjności, Toruń 2017, s. 183 n.

9 Więcej P. Nonet, P. Selznick, Law and Society in Transition: Toward Responsive Law, New Brunswick, NJ 2009, s. 73 n.

${ }^{10}$ Więcej w tej kwestii A. Bator, K. Kaczmarek, op. cit., s. 21 n. Zob. też P. Nonet, P. Selznick, op. cit., s. 70 .

11 Więcej J. Stelmach, Interpretacja bez granic, „Forum Prawnicze” 2011, nr 2 (4), s. 17;

B. Brożek, Poza interpretację. Odpowiedź Jerzemu Stelmachowi, „Forum Prawnicze” 2011, nr 2 (4), s. 19 n.; A. Bator, P. Kaczmarek, op. cit., s. 22.

${ }^{12} \mathrm{Na}$ tle stosowania przepisów KSH w zgodzie z Konstytucją zob. uwagi A. Chłopeckiego, O prymacie kapitału nad własnościa, [w:] Rozprawy z prawa prywatnego. Księga jubileuszowa dedykowana prof. W. Popiotkowi, Warszawa 2017, s. 287 n. Z perspektywy pluralizmu badanego w odniesieniu do poznania prawniczego J. Stelmach, Pozytywistyczne mity..., s. 14. W tej materii więcej A. Zoll, Okoliczności wyłączające bezprawność czynu (zagadnienia ogólne), Warszawa 1982, s. 104. 
tuacjach mamy do czynienia z trudnymi przypadkami ${ }^{13}$. Ma tu też zastosowanie test proporcjonalności ${ }^{14}$. Postrzeganie prawa w kategorii porządku uosabiającego istotne dla danej społeczności wartości oznacza z jednej strony proces jego odkodowywania na ich podstawie, $\mathrm{z}$ drugiej zaś przyjmowanie $\mathrm{w}$ związku $\mathrm{z}$ jego znacznym odformalizowywaniem i budowaniem instytucji otwartych etycznej odpowiedzialności za prawo. W formalno-dogmatycznym podejściu chodziło głównie o zabezpieczenie formalnej (konwencjonalnej) sprawiedliwości, tutaj natomiast także o materialnoprawne jej gwarancje. Trudno byłoby w tym miejscu pominąć konstatacje A. Stelmachowskiego, który stwierdza: „Moc prawa tkwi nie w elementach formalnych, lecz wewnętrznych wartościach, które ono uosabia”. Zatem oderwanie egzegezy przepisów prawnych od funkcji społecznych, jakim regulacje mają służyć, identyfikowane z formalizmem dogmatycznym, traktowane jest współcześnie z dezaprobatą przez niemal wszystkie kierunki teoretyczne w prawoznawstwie ${ }^{15}$. Gdy jednak będziemy dokonywać analizy orzecznictwa sądowego na tle stosowania przepisów k.s.h. o odpowiedzialności członków zarządu spółki kapitałowej z tytułu szkód wyrządzonej spółce niestarannym wykonywaniem przez nich mandatu, to się okaże, że formalistyczne podejście do sankcjonowania odpowiedzialności odszkodowawczej ma się dobrze z negatywnymi skutkami tego stanu dla budowania ładu korporacyjnego ${ }^{16}$.

13 Trafnie wskazują A. Radwan, Ł. Gorywoda (Zaskarżanie uchwat walnego zgromadzenia akcjonariuszy. Reformy $w$ Europie $i$ wnioski dla polskiego ustawodawcy, „Kwartalnik Prawa Prywatnego" 2009, z. 2, s. 492), że „Projektując optymalne rozwiązanie regulacyjne w zakresie zaskarżania uchwał walnego zgromadzenia, należy dążyć do wyważenia kolidujących interesów: z jednej strony interesu spółki i pewności obrotu (postulat trwałości decyzji korporacyjnych), z drugiej zaś akcjonariuszy mniejszościowych niezdolnych do przeforsowania swojej woli w procesie decyzyjnym (postulat weryfikacji decyzji korporacyjnych)”. Jednocześnie dodają: „Względy słusznościowe mogą uzasadniać kompensatę dla akcjonariuszy mniejszościowych, w przypadku, kiedy względy efektywności ekonomicznej uzasadniają pozbawienie ich prawa do skorzystania z instrumentów zmierzających do zniweczenia uchwały podjętej wolą większości. Alternatywą dla skarg kasatoryjnych są zatem powództwa odszkodowawcze".

${ }^{14}$ Zob. na tle stosowania art. 31 ust. 3 Konstytucji uwagi B. Banaszaka, op. cit., s. 181. Z perspektywy art. 31 ust. 2 Konstytucji (wolności człowieka) L. Garlicki, [w:] Konstytucja Rzeczypospolitej Polskiej. Komentarz, t. 3, red. L. Garlicki, Warszawa 2003, s. 11.

${ }^{15}$ Szeroko o mitach poznania prawniczego J. Stelmach, Pozytywistyczne mity..., s. 8 n. A. Sulikowski, K. Otręba (op. cit., s. 10) dostrzegają niekorzystne zjawisko konserwatyzmu prawniczego, wyrażającego się między innymi tym, że wątki krytyczne odnoszone do systemu prawa pojawiają się niezmiernie rzadko w doktrynie porządku kontynentalnego.

${ }^{16}$ Zob. w tej kwestii A. Opalski, K. Oplustil, Niedochowanie należytej staranności jako przestanka odpowiedzialności cywilnoprawnej zarządców spótek kapitałowych, PPH 2013, nr 3, s. 11 n., 22 n.; W. Popiołek, Członek zarządu spółki kapitałowej jako przedsiębiorca, [w:] Ius est ars boni et aequi: księga pamiatkowa dedykowana prof. J. Frackowiakowi, Wrocław 2018, s. 942; R. Stefanicki, Model staranności członków zarzq̨du spółki kapitałowej w świetle współczesnych wyzwań, [w:] Kodeks spółek handlowych po 15 latach obowiązywania, red. J. Frąckowiak, Warszawa 2018, s. 695 n. 


\section{IV}

Tworzenie prawa lub jego odczytywanie polegające na jego odseparowywaniu od aksjologicznego rdzenia jest wadą porządku normatywnego, ponieważ mija się $\mathrm{z}$ jego ratio essendi ${ }^{17}$. Nie ujmując znaczenia wchodzącej w pierwszej kolejności wykładni językowo-logicznej badanych przepisów, w doktrynie - moim zdaniem — trafnie przyjęto ${ }^{18}$, że właściwym kontestowaniem prawa jest jego pogłębione badanie na płaszczyźnie aksjologiczno-prakseologicznej. Pozwala ono sięgać do samej istoty prawa i ustalić, czy analizowane rozwiązanie prawne prawidłowo i skutecznie realizuje zakładane cele społeczne ${ }^{19}$. Pojawia się tutaj określona przestrzeń dla aktywizmu sędziowskiego, ukierunkowywana na kreatywną interpretację prawa, między innymi w drodze wypełniania zastanych pojęć legalnych stosowną do celów danego aktu treścią. Pozwalać to ma na dokonywanie sprawiedliwego osądu i rozstrzyganie zgodne ze społecznymi oczekiwaniami. Dotyczyć to może sytuacji, gdy treść jurydycznej decyzji nie jest bez reszty zdeterminowana „obiektywną" treścią przepisów prawa ${ }^{20}$ i rozumowanie prawnicze odchyla się od „modelu sylogistycznego" w stronę „modelu argumentacyjnego" 21 . Postulat, aby z pozytywistycznego, zakotwiczonego w dziewiętnastowiecznej dogmatyce i metodologii, podejścia do prawa prywatnego przenieść punkt ciężkości na badanie adekwatności regulacji do jej kontekstu gospodarczego i społecznego, nie jest nowością, zważywszy, że znajduje odniesienie w civil law tradition, w tym w klauzulach odsyłających do dobrej wiary, względów użyteczności prawa ${ }^{22}$ i poszanowania wymogu sprawiedliwości w obydwu jej postaciach ${ }^{23}$.

17 R. Kwiecień, op. cit., s. 41.

18 A. Szajkowski O metodzie badania prawa handlowego, [w:] Kodeks spółek handlowych po $15 \ldots$, s. 174.

${ }^{19} \mathrm{~W}$ podobnym duchu wypowiadają się A. Bator, P. Kaczmarek, op. cit., s. 35.

${ }^{20}$ Krytycznie w kwestii poszukiwania obiektywnego znaczenia przepisów A. Sulikowski, K. Otręba, op. cit., s. 9.

${ }^{21}$ Zob. w tej kwestii stanowisko B. Banaszkiewicza, Demokracja pod specjalnym nadzorem. Uwagi o sędziowskim aktywizmie i granicach zmian konstytucji, „Forum Prawnicze” 2011, nr 1 (3), s. 60; A. Kotowski, Modele dyskursów prawniczych, Toruń 2013, s. 87.

22 Utylitarne osądy moralne są traktowane jako oparte na racjonalnym rozumowaniu etycznym w sytuacji, gdy — zdaniem J. Baron, I. Ritov, Protected values and omission bias as deontological judgments, „Psychology of Learning and Motivation”, grudzień 2009, s. 133 n. — rozstrzygnięcia deontologiczne są osądami emocjonalnymi, z którymi związana jest tylko moralna racjonalizacja, uzasadnianie wcześniej podjętej decyzji. Między innymi nasuwa się tu historycznie myśl sędziego (W. Bukowiński, Wspomnienia z Kazachstanu, „Wołanie z Wołynia”, Biały Dunajec 2006, s. 53): „Да, Буковиньски, ты много народа испортил” („Tak, tak Bukowiński, zdemoralizowaliście dużo ludzi”).

${ }^{23}$ W. Dajczak, Projekt wspólnego europejskiego prawa sprzedaży - powrót do pytania o istotę tego, co wspólne dla nauki prawa, „Forum Prawnicze” 2012, nr 3 (11) s. 5. Trafnie podnosi R. Ostrihansky (Stanowienie i stosowanie prawa Unii Europejskiej-czy rzeczywiście niezgodne ze standardami państwa demokratycznego?, „Forum Prawnicze” 2010, nr 2, s. 20), że za niezmiernie cenne w dyskursie prawniczym należałoby uznawać tendencje zmierzające w kierunku „by myśl 
Odkrywanie treści prawa przez pryzmat wartości istotnych dla demokratycznej wspólnoty, które ono uosabia, następuje przede wszystkim na podstawie wzorców mających swoje źródło w Konstytucji. Wielokrotnie do tej podstawy porządku prawnego odwoływał się Trybunał Konstytucyjny. Między innymi w orzeczeniu z dnia 23 marca 1999 roku $^{24}$ podniósł, że skoro z ustawy zasadniczej wynika pewien system wartości, to na ustawodawcy ciąży obowiązek stanowienia prawa umożliwiającego ich ochronę w jak najszerszym zakresie ${ }^{25}$. Idąc konsekwentnie tym tokiem rozumowania, przyjmować się powinno, że również stosowanie prawa musi następować z poszanowaniem wartości, reguł i zasad umocowanych konstytucyjnie ${ }^{26}$. Należy bowiem spójnie postrzegać paradygmaty z zakresu stanowienia, rozumienia i stosowania prawa ${ }^{27}$. Interpretacja ma sens tylko w zastosowaniach, w konkretyzowaniu i aktualizowaniu zastanych pojęćc ${ }^{28}$. W konstytucji mamy też do czynienia z otwarciem systemu prawa stanowionego na wartości o charakterze prawnonaturalnym ${ }^{29}$. Przykładem sięgania wprost do tych pierwiastków jest nad-

naukowa w sferze prawoznawstwa [...] odnosiła się do aksjologicznych przesłanek tworzenia i stosowania określonego modelu rozwiązań prawnych (a więc i społecznych) i nie ograniczała się do dogmatycznej analizy konstrukcji legislacyjnych". Zob. również A. Bator, Post-analytical theory and philosophy of law: new problems, new research perspectives?, [w:] A Post-Analytical Approach to Philosophy and Theory of Law, red. A. Bator, Z. Pulka, Berlin 2019, s. $11 \mathrm{n}$.

${ }^{24}$ K 2/98, OTK ZU 1999, nr 3, poz. 38.

${ }^{25} \mathrm{~W}$ odniesieniu do odczytywania i aplikacji kontekstu konstytucyjnego z perspektywy prawa karnego, zob. uwagi K. Szczucki, W poszukiwaniu dóbr chronionych w Konstytucji, „Forum Prawnicze" 2011, nr 4-5, s. 55 n.

${ }^{26} \mathrm{Na}$ temat takiego podziału R. Alexy, On the satructure of legal principles, „Ratio Juris” 2000, nr 3, s. 295 n. Podobnie R. Dworkin, The model of rules, „The University of Chicago Law Review" 1967, nr 1, s. 14 n., więcej komentarz J. Helios, Sędziokracja w Unii Europejskiej? Uwagi w kontekście działalności interpretacyjnej Trybunału Sprawiedliwości Unii Europejskiej, [w:] Rządy prawa i europejska kultura prawna, red. A. Bator, J. Helios, W. Jedlecka, Wrocław 2014, s. 184 n.

27 Więcej S. Wronkowska, M. Zieliński, O korespondencji dyrektywy redagowania i interpretowania tekstu prawnego, „Studia Prawnicze” 1985, z. 3-4, s. 301 n. W kwestii szerokiego definiowania pojęcia stosowania prawa więcej Z. Radwański, M. Zieliński, System prawa prywatnego, red. M. Safjan, Warszawa 2007, s. 392 n.

28 J. Stelmach, Interpretacja ..., s. 16 n. Por. w tej kwestii stanowisko B. Brożka, op. cit., s. 25.

${ }^{29}$ Niektórzy autorzy przyjmują wręcz (K. Szczucki, op. cit., s. 50), że dobra o charakterze podstawowym dla człowieka nie czerpią swojej mocy z woli ustawodawcy, ale kształtowane są na prawie naturalnym. Na uwagę tu zasługuje koncepcja praw człowieka A. de Tocqueville'a, De la démocatieen Américque, Paris 1864, wstęp, O demokracji w Ameryce, przeł. M. Król, oprac. J. Szacki, Warszawa 1976, wprowadzenie. Piszący wskazuje we wstępie, że: „Spośród wszystkich nowych zjawisk, jakie przyciągnęły moją uwagę podczas pobytu w Stanach Zjednoczonych, najbardziej uderzyła mnie panująca tam powszechna równość możliwości. Spostrzegłem szybko nadzwyczajny wpływ, jaki ten podstawowy fakt wywiera na rozwój społeczeństwa, nadając pewien kierunek powszechnemu sposobowi myślenia i pewien bieg prawom, podsuwając rządzącym nowe idee i określone obyczaje rządzonym. Zauważyłem wkrótce, że następstwa tego faktu wykraczają daleko poza domenę obyczajów politycznych i praw oraz że w równym stopniu wpływają na cywilną 
rzędność nad innymi dobrami, zasługującymi również na ochronę prawną, przyrodzonej i niezbywalnej godności (art. 30 Konstytucji) ${ }^{30}$. Stanowi ona centralny punkt odniesienia systemu wartości (w tym praw na dobrach osobistych), wokół których zbudowano ustawę zasadniczą ${ }^{31}$. Z dorobku jurydycznego $\mathrm{w}$ tej materii zasadniczo wynika, że art. 30 Konstytucji nie jest wykorzystywany jako samoistny przedmiot ochrony prawnej. Ewolucyjnie dokonujący się rozwój refleksyjnego podejścia do prawa, z jego otwartością na wymiar etyczny, może utorować drogę do postrzegania godności w kategorii samoistnego wzorca i podstawy skargi konstytucyjnej. W tym kierunku poszła judykatura niemiecka, która wytoczyła kierunek na dowartościowanie godności w przestrzeni unijnego prawa ${ }^{32}$. „Le people nomme celui qui fait la loi et celui qui l'exécute [...] C'est donc réellement le peuple qui dirige $[\ldots]^{\prime 33}$.

Współczesna tendencja na rzecz postrzegania prawa w tytułowej dla niniejszego opracowania kategorii nośnika wartości — aktualizuje trafność sentencji wypowiedzianej przez S. Wyszyńskiego ,strach zapukał do drzwi, otworzyła mu odwaga, i nikogo tam nie było"34 _ prowokuje do popierania szerszego sięgania

społeczność i na rząd: kształtują poglądy, rodzą emocje, podpowiadają praktyczne rozwiązania oraz zmieniają wszystko, co nie jest ich własnym dziełem".

30 Więcej K. Complak, Zasada ochrony godności człowieka normatywnym nakazem obowiazujacym prawodawców i organy stosujace prawo, [w:] Wolności i prawa jednostki oraz ich gwarancje w praktyce, red. L. Wiśniewski, Warszawa 2006, s. 7. Na temat koncepcji godności w nurcie personalistycznym Z. Pulka, Godność człowieka - właściwość autonomiczna czy heteronomiczna, „Krytyka Prawa” 2018, nr 2, s. 597; M. Sadowski, Godność człowieka i dobro wspólne w papieskim nauczaniu społecznym, Wrocław 2010, s. 62.

${ }^{31}$ Więcej B. Banaszak, op. cit., s. 169 i wskazane przez autora orzecznictwo; P. Polak, J. Trzciński, Konstytucyjna zasada godności człowieka $w$ świetle orzecznictwa Trybunału Konstytucyjnego, „Gdańskie Studia Prawnicze” 40, 2018, s. 258. K. Complak akcentuje, że jedynie osoba ludzka jest bezcenna, co oznacza, że definicje powinny tu nawiązywać do cech konstytutywnych człowieka, a nie jego zachowań czy tym bardziej warunków bytu — Godność nie jest dobra na wszystko. Propozycja uporządkowania materii, [w:] Między konstytucjonalizmem polskim a latynoamerykańskim, red. M. Kłopocka-Jasińska, Wrocław 2020, s. 79, https://www.bibliotekacyfrowa.pl/dlibra/publication/115875/edition/107316/content.

${ }^{32}$ R. Stefanicki, Ochrona praw podstawowych a zasada swobodnego przepływu ustug, „Glosa” 2011, nr 3, s. 23 n. Zob. też na temat skargi S. Jarosz-Żukowska, B. Banaszak, Die Verfassungsbeschwerde in Polen, „Osteuropa-Recht” 2014, nr 3, s. 288 n.

${ }^{33}$ A. de Tocqueville, De la démocatie..., s. 2. Bardziej tę myśl rozwija T. Hueglin, Classical Debates for the 21st Century: Rethinking Political Thought, Toronto 2008, komentarze przy przypisach 70-71.

${ }^{34}$ https://www.zamyslenie.pl/autor/Wyszynski-Stefan-prymas/. 
w praktyce do maksymy promieniowania konstytucji ${ }^{35}$, zwłaszcza w odniesieniu do formułowania ocen pod kątem, czy zastany porządek normatywny, sposób jego wdrażania zdają egzamin skuteczności i słuszności ${ }^{36}$. Rozstrzyganiu dylematów teoretycznych nad funkcjonowaniem prawa towarzyszyć powinna ich korespondencja $\mathrm{z}$ budowaniem świadomości prawnej adresatów prawa, $\mathrm{w}$ tym $\mathrm{z}$ edukacją adeptów profesji prawniczej, zmierzającą w kierunku kształtowania responsywnej, dyskursywnej otwartości prawa na współczesne wyzwania. Występują w tym podejściu zjawiska łączenia wymiaru instytucjonalnego z indywidualnym osądem, w którego centrum powinno znajdować się przyjmowanie etycznej odpowiedzialności za prawo.

\title{
THE RIGHT BALANCE. LAW AS A BAND FOR VALUES. CONTRIBUTION TO THE DISCUSSION
}

\author{
Summary
}

The material requirement of the rule of law refers to the content of law, values constructed on the basis of axiological and praxeological criteria of law. The responsive approach is about rational and selective reaching for signals coming from the environment of rights, including the education of practitioners in the legal profession. All this takes place primarily on the basis of patterns having their source in the Constitution.

Keywords: legal order, axiological and praxeological criteria, discursive openness, ethical dimension, responsive model

\section{BIBLIOGRAFIA}

Alexy R., On the structure of legal principles, „Ratio Juris” 2000, nr 3.

Banaszak B., Konstytucja Rzeczpospolitej Polskiej. Komentarz, Warszawa 2009.

Banaszkiewicz B., Demokracja pod specjalnym nadzorem. Uwagi o sędziowskim aktywizmie i granicach zmian konstytucji, „Forum Prawnicze” 2011, nr 1 (3).

Baron J., Ritov I., Protected values and omission bias as deontological judgments, „Psychology of Learning and Motivation", grudzień 2009.

Bator A., Kaczmarek P., Kim ma być wychowanek akademii prawniczej?: o perspektywach budowania edukacji prawniczej wokót konstytucji, „Krytyka Prawa” 2018, nr 2.

35 To promieniowanie należałoby odnosić nie tylko do badania zgodności ustawodawstwa zwykłego z konstytucją, ale także samodzielnej interpretacji jej tekstu. Więcej na temat oddziaływania konstytucji E. Łętowska, Promieniowanie orzecznictwa Trybunału Konstytucyjnego na poszczególne gatęzie prawa, [w:] Księga XX-lecia orzecznictwa Trybunatu Konstytucyjnego, red. M. Zubik, Warszawa 2006, s. 353 n.

36 Parallèlement, il convient de trouver un juste équilibre entre la simplification et la stabilité des règles et procédures (Równocześnie trzeba znaleźć właściwą równowagę między uproszczeniem a stabilnością przepisów i procedur). 
Bator A., Post-analytical theory and philosophy of law: new problems, new research perspectives?, [w:] A Post-Analytical Approach to Philosophy and Theory of Law, red. A. Bator, Z. Pulka, Berlin 2019.

Brożek B., Poza interpretację. Odpowiedź Jerzemu Stelmachowi, „Forum Prawnicze” 2011, nr 2 (4).

Bukowiński W., Wspomnienia z Kazachstanu, „Wołanie z Wołynia”, Biały Dunajec 2006.

Chłopecki A., O prymacie kapitału nad własnościa, [w:] Rozprawy z prawa prywatnego. Księga jubileuszowa dedykowana prof. W. Popiołkowi, Warszawa 2017.

Complak K., Godność nie jest dobra na wszystko. Propozycja uporządkowania materii, [w:] Między konstytucjonalizmem polskim a latynoamerykańskim, red. M. Kłopocka-Jasińska, Wrocław 2020.

Complak K., Zasada ochrony godności człowieka normatywnym nakazem obowiąującym prawodawców i organy stosujace prawo, [w:] Wolności i prawa jednostki oraz ich gwarancje w praktyce, red. L. Wiśniewski, Warszawa 2006.

Dajczak W., Projekt wspólnego europejskiego prawa sprzedaży — powrót do pytania o istotę tego, co wspólne dla nauki prawa, „Forum Prawnicze” 2012, nr 3 (11).

Duguit L., Kierunki rozwoju prawa cywilnego od poczatku XIX wieku, przeł. S. Sieczkowski, Warszawa-Kraków 1938.

Dworkin R., The model of rules, „The University of Chicago Law Review” 1967, nr 1.

Garlicki L., [w:] Konstytucja Rzeczypospolitej Polskiej. Komentarz, t. 3, red. L. Garlicki, Warszawa 2003.

Gromski W., Law and economics jako teoria polityki prawa, [w:] Analiza ekonomiczna w zastosowaniach prawniczych, red. J. Stelmach, M. Soniewicka, Warszawa 2007.

Helios J., Sędziokracja w Unii Europejskiej? Uwagi w kontekście dziatalności interpretacyjnej Trybunału Sprawiedliwości Unii Europejskiej, [w:] Rzady prawa i europejska kultura prawna, red.

A. Bator, J. Helios, W. Jedlecka, Wrocław 2014.

Hueglin T., Classical Debates for the 21st Century: Rethinking Political Thought, Toronto 2008.

Jacyszyn J., Dobre praktyki spółek giełdowych, ,Przegląd Ustawodawstwa Gospodarczego” 2016, nr 2.

Jarosz-Żukowska S., Banaszak B., Die Verfassungsbeschwerde in Polen, „Osteuropa-Recht” 2014, nr 3.

Korycka-Zirk M., Filozoficznoprawny wymiar kontroli konstytucyjności, Torun 2017.

Kotowski A., Modele dyskursów prawniczych, Torun 2013.

Kwiecień R., Wartości i prawo a kreatywność porzadku prawnego, „Forum Prawnicze” 2010, nr 1 (1).

Łętowska E., Promieniowanie orzecznictwa Trybunału Konstytucyjnego na poszczególne gałęzie prawa, [w:] Ksiega XX-lecia orzecznictwa Trybunału Konstytucyjnego, red. M. Zubik, Warszawa 2006.

Morawski L., Główne problemy wspótczesnej filozofii prawa. Prawo w toku przemian, Warszawa 2005.

Nonet P., Selznick P., Law and Society in Transition: Toward Responsive Law, New Brunswick, NJ 2009.

Opalski A., Oplustil K., Niedochowanie należytej staranności jako przesłanka odpowiedzialności cywilnoprawnej zarządców spółek kapitałowych, PPH 2013, nr 3.

Ostrihansky R., Stanowienie i stosowanie prawa Unii Europejskiej - czy rzeczywiście niezgodne ze standardami państwa demokratycznego?, „Forum Prawnicze” 2010, nr 2 (2).

Polak P., Trzciński J., Konstytucyjna zasada godności człowieka w świetle orzecznictwa Trybunatu Konstytucyjnego, „Gdańskie Studia Prawnicze” 40, 2018.

Popiołek W., Członek zarządu spółki kapitałowej jako przedsiębiorca, [w:] Ius est ars boni et aequi: ksiega pamiątkowa dedykowana prof. J. Frackowiakowi, Wrocław 2018.

Pulka Z., Godność człowieka - właściwość autonomiczna czy heteronomiczna, „Krytyka Prawa” 2018, nr 2.

Radwan A., Gorywoda Ł., Zaskarżanie uchwat walnego zgromadzenia akcjonariuszy. Reformy w Europie i wnioski dla polskiego ustawodawcy, „Kwartalnik Prawa Prywatnego” 2009, z. 2. 
Radwański Z., Zieliński M., System prawa prywatnego, red. M. Safjan, Warszawa 2007.

Sadowski M., Godność człowieka i dobro wspólne w papieskim nauczaniu społecznym, Wrocław 2010.

Sokolewicz W., [w:] Konstytucja Rzeczypospolitej Polskiej. Komentarz, t. 4, red. L. Garlicki, Warszawa 2005.

Stefanicki R., Model staranności członków zarządu spółki kapitałowej w świetle współczesnych wyzwań, [w:] Kodeks spółek handlowych po 15 latach obowiązywania, red. J. Frąckowiak, Warszawa 2018.

Stefanicki R., Ochrona praw podstawowych a zasada swobodnego przeplywu uslug, „Glosa” 2011, nr 3.

Stelmach J., Interpretacja bez granic, „Forum Prawnicze” 2011, nr 2 (4).

Stelmach J., Pozytywistyczne mity metody prawniczej, „Forum Prawnicze” 2012, nr 3.

Sulikowski A., Otręba K., O potrzebie studiów krytycznych nad prawem konstytucyjnym, „Państwo i Prawo" 2017, nr 3.

Szajkowski A., O metodzie badania prawa handlowego, [w:] Kodeks spółek handlowych po 15 latach obowiązywania, red. J. Frąckowiak, Warszawa 2018.

Szczucki K., W poszukiwaniu dóbr chronionych w Konstytucji, „Forum Prawnicze” 2011, nr 4-5.

Tocqueville A. de, De la démocatieen Américque, Paris 1864.

Tocqueville A. de, O demokracji w Ameryce, przeł. M. Król, oprac. J. Szacki, Warszawa 1976.

Wronkowska S., Zieliński M., O korespondencji dyrektywy redagowania i interpretowania tekstu prawnego, „Studia Prawnicze” 1985, z. 3-4.

Zoll A., Okoliczności wyłączające bezprawność czynu (zagadnienia ogólne), Warszawa 1982.

Żak M., O możliwych zastosowaniach idei good governance w naukach prawnych i praktyce prawniczej, „Państwo i Prawo” 2019, nr 9. 